\title{
Esters of Organophosphorus Acids - Toxicity, Application and Removal from the Environment
}

\author{
Vladan J. Anićijević ${ }^{1,2}$ \\ Tamara D. Lazarević-Pašti ${ }^{3)}$ \\ Dragana D. Vasić Anićijević ${ }^{3)}$ \\ Radovan M. Karkalić ${ }^{4)}$
}

\begin{abstract}
Esters of organophosphorus acids (OPs) are widely used nowadays. They have an application as pesticides, drugs or chemical warfare agents. Their acute toxicity is ascribed to the inhibition of acetylcholinesterase (AChE), a key enzyme in the transmission of nerve impulses in mammals. Their toxic effects are manifested by the accumulation of acetylcholine and can lead to the paralysis or death. OPs poisoning therapy is based on the application of specific antidotes as well as non-specific and symptomatic procedures. In this contribution, recent achievements concerning the protection from OPs activity and an overview of the methods for their removal from the environment and decontamination of contaminated persons were presented
\end{abstract}

Key words: esters of organophosphorus acids, pesticides, nerve agents, toxicity, environment, remediation.

\section{Introduction}

History of development and application of $O P S$

DEELOPMENT of organophosphorus (OP) chemistry began in the $19^{\text {th }}$ century, when Jean Louis Lassaigne synthesized triethyl phosphate in the reaction of ethanol and phosphoric acid [1]. Philippe de Clermont synthesized tetraethylpyrophosphate (TEPP) in 1854, which was the first OP compound used as an insecticide. Later, the series of highly toxic OP compounds with cyano-group $(\mathrm{P}-\mathrm{CN})$ or a fluorine atom (P-F) bonded directly to a phosphorus atom were synthesized [2,3]. German chemist Gerhard Schräder recognized the potential of TEPP as an insecticide and synthesized the first commercial OP formulation - an insecticide product containing this compound as an active ingredient [4].

Although the research has been initiated in order to obtain new insecticides, later it resulted in the discovery of chemical warfare agents (CWA) with nervous-paralytic effects. The first one from the group of these compounds, tabun, was synthesized in 1936, leading to the history of development and application of OPs as nerve poisons [4]. The next synthesized CWAs were sarin and soman [1]. The synthesis of these compounds as chemical weapons has drawn the attention of the scientific community to the development of the methods of protection against its use in combat operations and potential terroristic activities [1,5]. After the synthesis of disopropylfluorophosphate (DFP), the anticholinesterase (anti-ChE) activity of the OP was observed. The term anti-AChE is a common name for all types of acetylcholinesterase (AChE) inhibitors, including irreversible, reversible and slow substrates, as well as transition state analogues. For a long time, DFP has been an inevitable model-compound for the study of the pharmaco-toxic and toxico-dynamic effects as an inhibitor of the enzymes from the $\mathrm{ChE}$ group. At the same time, systemic insecticide tetraisopropylpyrophosphoramide (iso-OMPA) was synthesized $[1,5]$. After the Second World War, research on the synthesis of new CWA was continued and the G series containing isopropylmethyl phospho-nofluoridate (GE) and cyclosarin were synthesized. Further, the synthesis of amitone, a new CWA series of OPs, known as V-poisons, was created with the most famous VX poison among them $[4,6]$.

\section{Structure of OPS}

By their chemical composition OPs compounds are esters, thioesters, anhydrides or halides of completely substituted phosphoric, phosphonic or phosphinic acids. In 1937, Schräder gave the general chemical structure formula of the OP of the anti-ChE type, which was later developed into the structures representing the general (a) and modified (b) formulas of OP compounds, presented in Fig.1.<smiles>[R]P([R])([R])=[Si]</smiles><smiles>[R]P([R])(=O)[X]N=C(C)C</smiles>

Figure 1. Structural formula of OPs: (a) general; (b) modified

According to Schräder, any organic phosphorus compound should be biologically active if it has the following features:

- Oxygen or sulfur linked by a double covalent bond with pentavalent phosphorus,

\footnotetext{
1) Faculty of Physical Chemistry, University of Belgrade, Studentski trg 12-14, Belgrade, SERBIA

2) Military Technical Institute (VTI), Ratka Resanovića 1, 11132 Belgrade, SERBIA

3) Vinča Institute of Nuclear Sciences, University of Belgrade, PO Box 522, Beograd, SERBIA

4) Military Academy, University of Defence in Belgrade, Pavla Jurišića Šturma 33, Belgrade, SERBIA

Correspondence to: Radovan Karkalić, e-mail: rkarkalic@yahoo.com, radovan.karkalic@va.mod.gov.rs
} 
- $\mathrm{R}_{1}$ and $\mathrm{R}_{2}$ are alkyl groups bonded to the phosphorus via oxygen (alkoxy -OR or aryloxy -OAr groups), nitrogen (amido group $-\mathrm{NR}_{2}$ ) or directly (alkyl $-\mathrm{R}$ and aryl $-\mathrm{Ar}$ groups), as well as alkylthio-, N-alkyl and N,N-dialkylamino groups,

- Contains $\mathrm{R}_{3}$ as an acidic residue of an inorganic or organic acid $\left(\mathrm{F}^{-}, \mathrm{CNS}^{-}, \mathrm{RCOO}^{-}\right)$, as well as some other groups (enolates, mercaptides).

With the development of the chemistry of organic phosphorus compounds, the general formula of Schräder was modified by replacing $\mathrm{R}_{3}$ group with $-\mathrm{XAM}$ group bound to $\mathrm{P}$, where $\mathrm{X}, \mathrm{A}$ and $\mathrm{M}$ represent $\mathrm{H}, \mathrm{C}, \mathrm{N}, \mathrm{O}, \mathrm{S}$, and halogen atoms. In compounds with good pesticide properties, the $\mathrm{P}$ $\mathrm{X}$ bond is weaker, and $\mathrm{M}$ group is more electronegative or becomes electronegative under the influence of protons or reducing agents, attracting the inductive effect of the $\mathrm{P}-\mathrm{X}$ electrons. The condition for this is the introduction of atom A with $s p^{2}$ hybridization (Fig.1b). This structure represents the basic structure for all compounds with phosphorylating properties, where $\mathrm{X}, \mathrm{A}$ and $\mathrm{M}$ represent hydrogen, carbon, nitrogen, oxygen, and halogen atoms. The modified Schräder formula can explain the behavior of OPs, the need for the synthesis of new compounds in which radicals are different heterocyclic compounds, as well as the toxicity and potential protolytic properties of the molecules [1,2]. Basically, the chemical reactions and toxicity of these compounds depend strongly on their structure that contains an electrophilic phosphorus atom with an electron deficiency.

Therefore, the interaction with nucleophilic reactants is characteristic for these compounds [1], which is followed by breaking $\mathrm{P}-\mathrm{X}$ bond, where $-\mathrm{X}$ is an electron-acceptor substituent relative poorly bound to the phosphorus atom. In case of CWA it is $\mathrm{CN}$ in the taboo, $\mathrm{F}$ in sarin and $\mathrm{SCH}_{2} \mathrm{CH}_{2} \mathrm{NR}_{2}$ in VX. Moreover, it is characteristic for $\mathrm{VX}$, that the bonds become weaker due to the interaction of the electron pair of sulphur atoms with a positively charged atom of nitrogen, thus creating conditions for its easy leaving.

\section{Classification of OPs}

OPs compounds are divided according to the nature of the substituent that surrounds the central phosphorus atom and contain a number of oxygen, sulfur, nitrogen atoms or their combinations [1]. Due to different nature of the substituent attached to the central phosphorus atom, the classification of the OPs is very complex. The literature surveys indicate that there are 32 groups of OP (20 phosphates and 12 phosphonates), and some of them are shown in Fig.2 [7].<smiles>[R]OP([R])([R])=O</smiles>

phosphates<smiles>[R]OP([R])([R])=S</smiles>
phosphonothioates :S and -S<smiles>[R]OP([R])([R])=O</smiles>

phosphonates

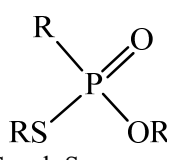<smiles>[R][P+]([R])([R])[O-]</smiles>
phosphinates

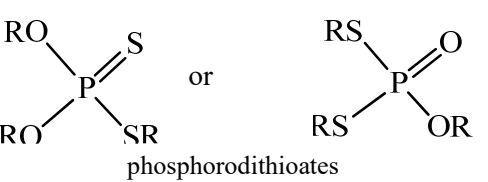<smiles>[R]OP([R])(=O)F</smiles>
phosphonofluorides phosphorofluoridates phosphine oxides<smiles>[R20][R]([R20])([R2])[O-]</smiles>
phosphoroamidates<smiles>[R20]P([R20])([R2])=S</smiles>

or<smiles>[R2]NP([R2])([R2])=O</smiles>
phosphorodiamidates<smiles>[R20]P([R6])([R20])=O</smiles>

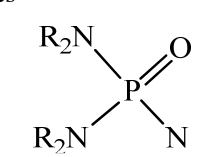

phosphorothriamides<smiles>[R20]P([R20])([R20])=S</smiles><smiles>[R20]P([R20])(=O)F</smiles>

$\mathrm{RS}$ phosphoroamidotioates<smiles>[R20]P([R20])(=O)Cl</smiles>

phosphorohlorides<smiles>[R]OP([R])(=O)OP([R2])(=O)[O-]</smiles>

pyrophosphates<smiles>[R20]P(=O)(Cl)Cl</smiles>

phosphorodichloridates (S) R<smiles>[R20]P([R6])([R])=O</smiles>

phosphorothiotes :S and -S

phosphoroamidofluridates<smiles>[R10]P(C)(C)=S</smiles>
phosphoroamidodithioates<smiles></smiles>
phosphoroamidocyanidates<smiles>[R]OP([R])([R])=O</smiles>

pyrophosphonates<smiles>[R5]P([R5])([R5])=O</smiles><smiles>[R][R]([R])(=O)F</smiles>

phosphinofluoride

$$
\text { HNR }
$$<smiles>[R11]CCC</smiles>

phosphorodiamidofluridates

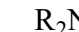<smiles>[R1]NP(=O)([14CH2][14CH2][14CH2][14CH3])N[R1]</smiles><smiles></smiles>

pyrophosphoroamidates

Figure 2. Structures of some groups of OPs. (:S) represents sulphur bonded to phosphorous by coordinative - covalent bond; (-S) sulphur bonded to phosphorous by the ester bond 
In these groups, phosphates, phosphonates and phosphinates are derivatives of phosphoric, phosphonic and phosphinic acids in which the central phosphorus atom is surrounded by carbon or oxygen atoms. Phosphorothioates, phosphonothioates, phosphorodithioates, and phosphorotrithioates contain sulphur directly attached to the phosphorus atom. Similarly, phosphoroamidates contain one nitrogen atom instead of oxygen, and the phosphoroamidothioates contain nitrogen and sulphur. OPs include also pyrophosphates (phosphoric anhydrides). In the CWA group (such as sarin, soman, DFP and some pesticides) one of the-OR groups is replaced by a fluorine atom (phosphorophluoridates and phosphonofluoridates). CWA VX is a phosphonate (leaving group -SR), while tabun, which belongs to the phosphate group, contains $\mathrm{P}$ bonded to the $\mathrm{C}$ atom of the cyano group [1].

\section{Toxic effects of OPs}

Due to their extremely frequent use in agriculture, OPs reach the human body mainly through a food chain [8-11]. Their toxic effects are particularly pronounced due to the transition from thio- $(\mathrm{P}-\mathrm{S})$ to analogous oxo-forms $(\mathrm{P}-\mathrm{O})$, which occurs by biotransformation in the human organism [12-16].

\section{Influence of OPs on cholinesterases}

The common feature of OPs is high toxicity towards mammals $[3,5,17]$. By developing new structures within this group of compounds, less toxic OPs were formed, which in turn quickly became the leading class of compounds among insecticides [12]. OPs are specific inhibitors of AChE and butyrylcholinesterase (BChE), whose primary physiological functions are hydrolysis of acetylcholine (ACh) and butyrylcholine $(\mathrm{BCh})$ in cholinergic synapses in the central and peripheral nervous system [1]. The active center of AChE consists of an anionic and ester sites defined by a specific amino acid sequence and a distance of about $0.5 \mathrm{~nm}$. A schematic presentation of the binding sites of AChE activity modulators on the enzyme is given in Fig.3.

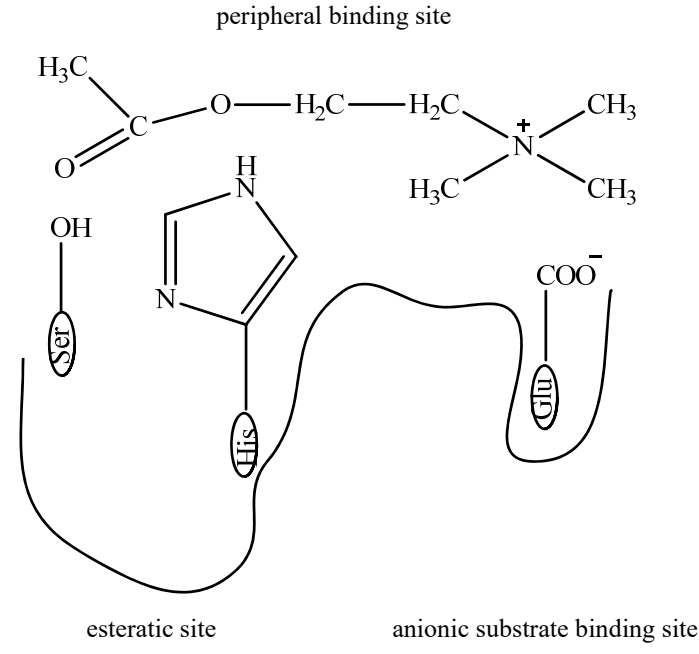

Figure 3. Schematic presentation of AChE binding sites

Phosphorylation of the enzyme involves the entry of OPs into the active site of the enzyme, a $2 \mathrm{~nm}$ deep gorge with Ser 203 at the bottom, which makes the catalytic triad with His 447 and Glu 334. It is an ester site that performs the catalytic function of the enzyme, allowing a nucleophilic attack on ACh and hydrolysis of the substrate.
Metabolic bioactivation is required for the phosphorylation of an enzyme in the presence of compounds containing sulphur which is bonded to a phosphorus atom by a coordinate-covalent bond. It is worthy to notice that only compounds with an oxygen atom bound to phosphorus are capable of phosphorylating AChE [18]. Therefore, the bioactivation includes oxidative desulfuration, which is mainly performed in the liver under the influence of cytochrome P-450 enzymes (CYP-450). Although this reaction has been known for decades, the exact CYP-450 isoform that catalyzes oxidative desulfuration is still unknown [19]. In the reactions of biotransformation of OP compounds, the transformation of non-toxic OPs into respective toxic form can occur, as well as the transformation of one toxic into another toxic compound. In addition, there is also the possibility of chemical transformation of toxic OP compounds into compounds that do not have the potency to inhibit AChE.

\section{The mechanism of AChE inhibition}

OPs inhibit AChE activity irreversibly due to the covalently binding to the active site of the enzyme [14,20]. This is schematically presented in Fig.4. The first step in the mechanism (step 1) of AChE activity inhibition in the presence of OPs is the formation of a reversible complex between the acetyl group of an enzyme and inhibitor [3,12,21]. At the molecular level, the inhibition begins with the formation of an unstable bond between the oxygen of the OP compound and the proton of imidazolium ion, which reduces the electron density of the phosphorus atom. At the same time, the intramolecular hydrogen bond between hydroxyl groups of Ser and Tyr is formed, thereby increasing the electron density on the oxygen atom of Ser. These reactions facilitate the nucleophilic attack on the phosphorus atom, leading to formation of transition state TS I. The hydroxyl group of Ser reacts with the phosphate ester, leading to alcohol elimination followed by Ser 203 phosphorylation (step 2). In a further series of reactions, another molecule of alcohol is eliminated.

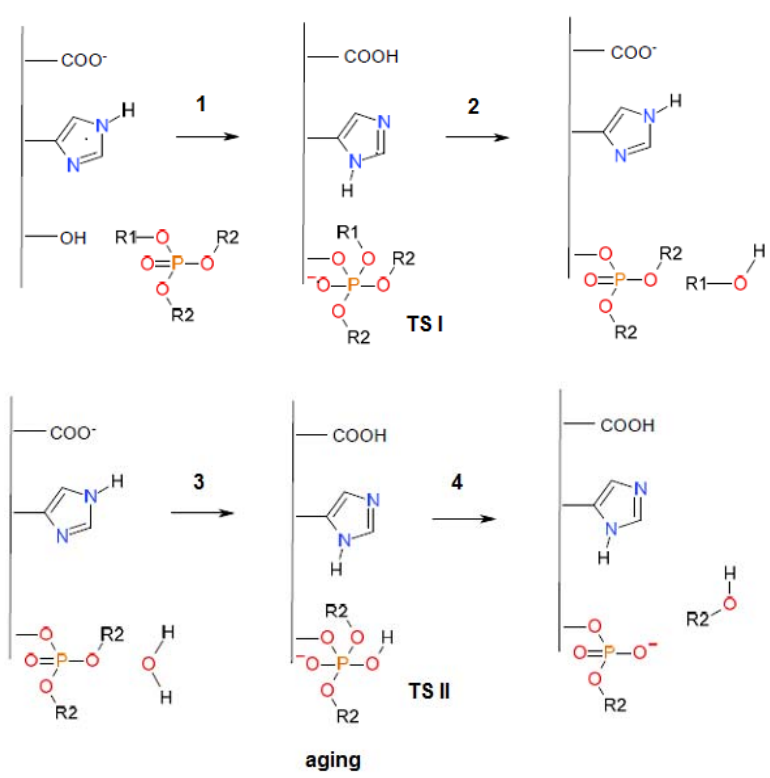

Figure 4. Mechanism of reversible inhibition of AChE induced by OPs

In step 3, one molecule of water exerts nucleophilic attack on phophoryilated serine residue, leading to formation of transition state TS II. In the step 4, R2-OH group is 
eliminated. Once the molecule loses its R2-OH group (dealkylation), AChE can no longer be reactivated, a process is called aging. After this step, the enzyme is irreversibly inhibited.

When OPs molecule contains methyl or ethyl substituent, the spontaneous enzyme regeneration takes several hours. The inhibitory potential of the OPs increases by extending the alkane chain of the substituent, and spontaneous reactivation of the enzyme is negligible. The phosphorylated enzyme cannot hydrolyze ACh, and the inhibition of AChE leads to the accumulation of this neurotransmitter. Thus, the post-synaptic membrane remains depolarized and synaptic transmission does not work. The difference in the behavior of ACh as a substrate and OPs as toxic inhibitors is in the rate of the reactivation of the enzyme. The acyl-enzyme formed in the reaction of the enzyme and ACh rapidly hydrolyzes and regenerates to the free enzyme. The regeneration (deacetylation) of enzymes occurs due to the hydrolysis of the ester bond and is followed by the formation of imidazolium ions. On the other hand, enzyme regeneration after phosphorylation in reaction with OPs is very slow. Phosphorylated AChE is a very stable complex, so the activity of enzymes in OPs poisoning without therapy with reactivators cannot be restored. Particularly toxic effects are expressed by the CWA from the OPs group. [17,19]

\section{Symptoms and manifestation of OPs toxic effects}

The toxic effects of OPs are the consequence of an excessive accumulation of the AChE substrate - ACh, due to the inhibition of AChE activity. They are manifested by numerous adverse effects on muscarinic and nicotinic receptors in the central or peripheral nervous system. These include Alzheimer's disease, learning difficulty, reduced physical coordination in children, and many other problems listed in Table 1. In extreme cases, these symptoms can lead to death due to paralysis of the respiratory center or respiratory muscles [22].

Table 1. Symptoms manifested in the organism as a consequence of the irreversible inhibition of AChE

\begin{tabular}{||c|c|c||}
\hline $\begin{array}{c}\text { ACh accumula- } \\
\text { tion site }\end{array}$ & \multicolumn{1}{c|}{ Symptoms } \\
\hline \hline $\begin{array}{c}\text { Central nerve } \\
\text { system }\end{array}$ & $\begin{array}{c}\text { dizziness, headache, anxiety, tremor, confusion, the } \\
\text { decline in concentration, mental convulsions, coma } \\
\text { and depression of respiratory (paralysis) cramps of } \\
\text { fear and confusion insomnia, vertigo, sleeplessness, } \\
\text { speaking disorders }\end{array}$ \\
\hline \multirow{3}{*}{$\begin{array}{c}\text { Peripheral } \\
\text { autonomic nerve } \\
\text { system }\end{array}$} & Nicotinic & $\begin{array}{l}\text { tachycardia, convulsions, muscle } \\
\text { weakness, fasciculation and/or paraly- } \\
\text { sis of skeletal smooth muscles, dia- } \\
\text { phragms and intercostal respiratory } \\
\text { muscles, hypertension uncontrolled } \\
\text { muscle contractions and paralysis }\end{array}$ \\
\cline { 2 - 4 } & Muscarinic \\
symptoms & $\begin{array}{l}\text { increased elimination (salivation, per- } \\
\text { spiration, lachrymation), indigestion } \\
\text { (spasms, vomiting, diarrhea), lowered } \\
\text { heartbeat, visual disorders, increased } \\
\text { gastric secretion, rhinorrhea, myositis, } \\
\text { abdominal cramps, diarrhea, frequent } \\
\text { urination, bronchial hypersecretion, } \\
\text { bronchospasm, bronchoconstriction }\end{array}$ \\
\hline \hline
\end{tabular}

CWA from the group of OPs exert nerve-paralytic effects and belong to the most toxic synthetic compounds [23]. They have neither smell nor taste and exhibit significant environmental stability, act very quickly, especially when present in high concentrations. Moreover, they do not leave visible traces on the poisoned body and have a cumulative effect that exceeds all known synthetic poisons so far. The lowest limit of irritation is the minimal concentration of CWA needed to induce toxic effects on the body. For example, $10 \mathrm{mg} \mathrm{VX}$ induces lethal effects for an adult within 20 minutes after percutaneous contamination, while the lethal dose of sarin $(0.01 \mathrm{mg} / \mathrm{kg}$ for human $)$ due to inhalation exerts its activity after $2 \mathrm{~min}$.

Previously, it was considered that CWA influence the body acutely, by inhibiting the enzyme of the nervous system, mainly $\mathrm{AChE}$, whereas low doses do not leave (visible) consequences on the body. However, OPs also inhibit other physiologically important enzymes and therefore influence on many biochemical processes $[14,24,25]$. There are some examples, such as $\gamma$-amino-butyric acid, catecholamines and the inhibition of at least enzymes that participate in physiological processes in the cell (myeloperoxidase, succinate dehydrogenase, sodium potassium ATPase, etc.). CWA disrupt adenocorticotropic hormone concentrations, and hence all the processes dependent on these hormones (especially in the nervous, reproductive and immune systems). In this way, OPs interfere with all processes in the organism in which inhibited enzymes are involved, such as the production of liver enzymes, regulation of full and adrenocorticotropic hormones, inflammation, and others [25].

\section{Antidotes}

The therapy of OPs induced poisoning implies the application of specific antidotes as well as the classical nonspecific and symptomatic measures and procedures [26-28]. Irreversibly inhibited enzymes can regenerate their activity only in the presence of $\mathrm{AChE}$ reactivators. The most common compounds used to restore $\mathrm{AChE}$ activity are those from the oxime group, such as pyridine-2-aldoximes (2-PAM) and 1,1trimethylene-bis-(4-formyl-pyridinium bromide) dioxides (TMB-4). They can restore the inhibited enzyme activity within a few minutes. However, due to the ageing of the pesticideenzyme complex, the enzyme reactivation becomes impossible [26,29].

Standard therapy implies the reduction of OPs absorption by stomach due to the administration of activated carbon, accompanied by the administration of an antidote to suppress the effects of the absorbed pesticides [26]. Within the specific therapy, atropine is used as a muscarinic receptor antagonist and oximes as reactivators of inhibited AChE activity. Conventional therapy also implies the use of benzodiazepines, which are effective anticonvulsants, as determined on the basis of experimental results on rodents and primates [30].

The pharmacological antidote atropine is a competitive AChE antagonist administered intravenously or intramuscularly every 30 minutes, due to its rapid degradation before the signs of atropinization appear (dry mouth, skin, facial flushing, tachycardia, enlarged pupils). Atropine stops the muscarinic effect, while on nicotine it does not work. On the other hand, oximes remove the muscarinic and nicotinic effects, while there is no effect on the central nervous system. These compounds reactivate $\mathrm{AChE}$ by removing the phosphoryl group. Most commonly used are pyridine oximes such as pralidoxime chloride (2-PAM) or mesylate, P2S (against sarin, cyclosarin and VX poisons), trimedoxime or TMB-4 and obidoxime or LüH-6 (both against tabun, sarin and VX- poisons), HI-6 (against sarin, soman, cyclosarin and VX poisons) and HLö-7 (against all five nerve poisons). Experimental and clinical experiences show that only trimedoxime and obidoxime can reactivate $\mathrm{AChE}$ with an antidotal protection against most OPs insecticides [31,32]. The search for "omnipotent" oxime, 
effective against all CWA and OP insecticides, is still in progress $[33,34]$.

\section{Application of OPs}

OPs are widely used in agriculture in the protection of plants [2]' such as insecticides, herbicides, fungicides, plant growth regulators, rodenticides and as chemosterilants. These compounds may have a role as chemical weapons in chemical warfare, and some of the organic phosphorous compounds are used as medicines [21,35]. Table 2 provides a list of mostly used OPs with chemical formulas and the IUPAC name.

Table 2. List of some commonly used OPs

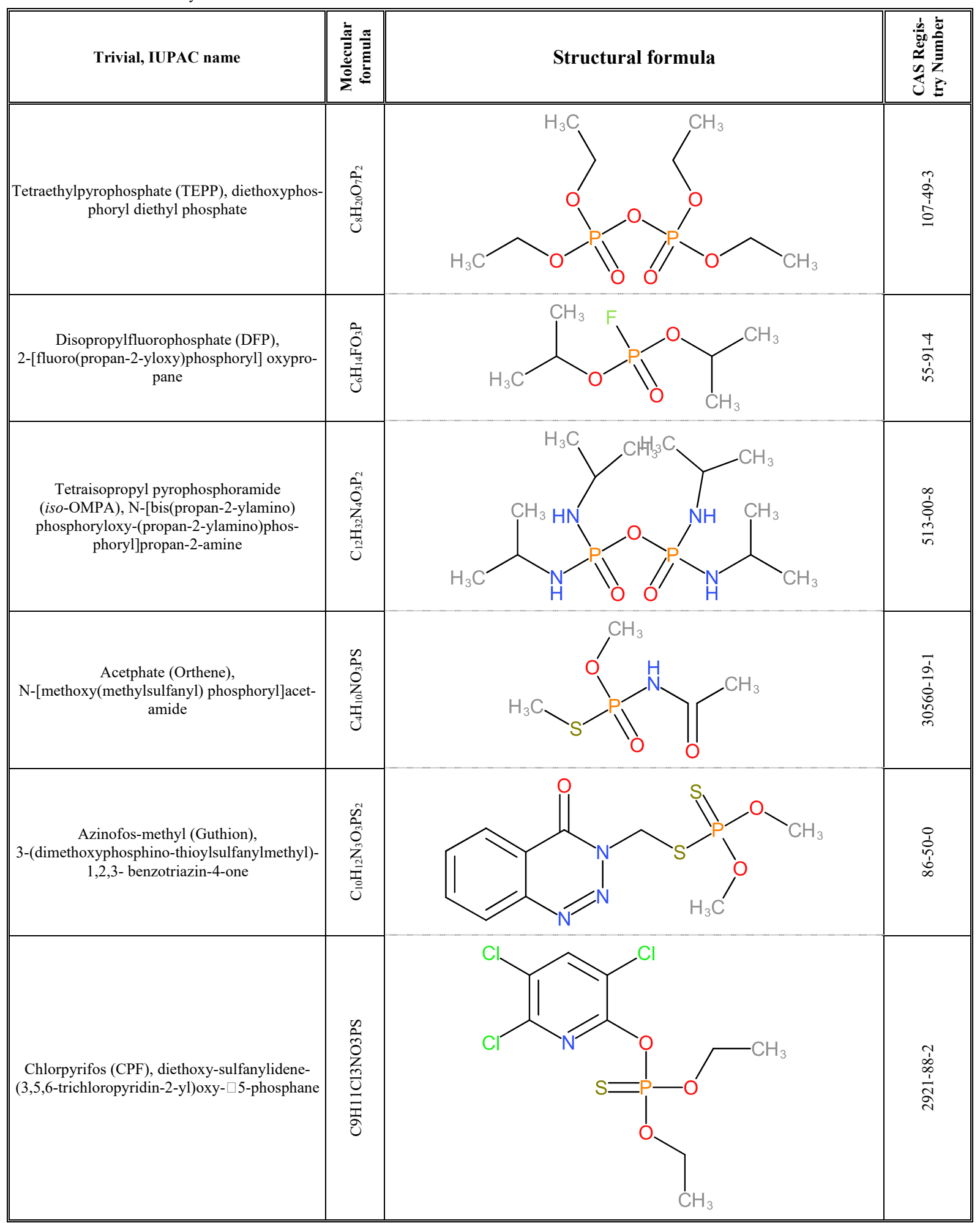




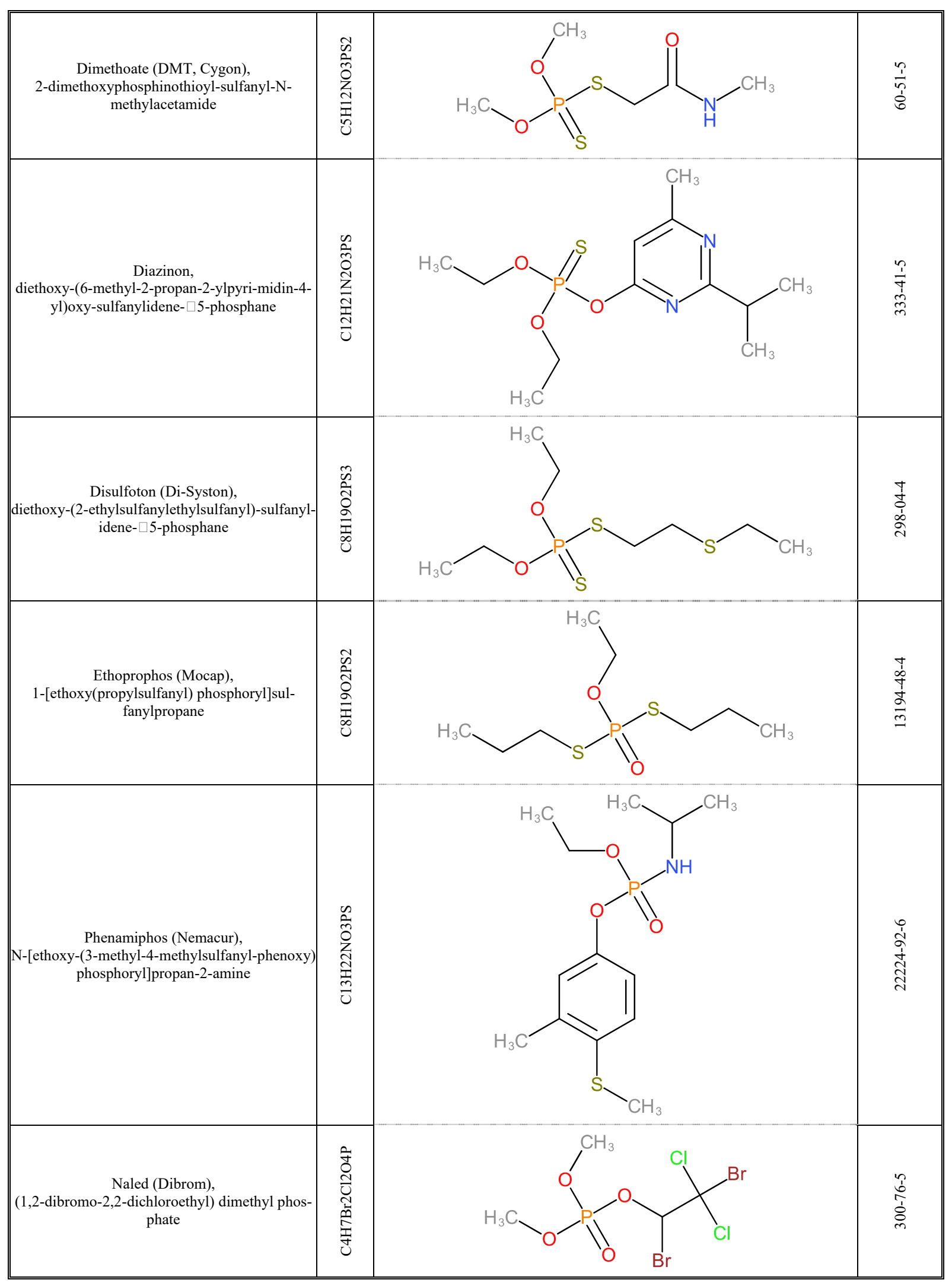


Malathion (Fyfanon),

diethyl 2-dimethoxyphosphino-thioylsulfanylbutanedioate

Metamidophos (Monitor), [amino(methylsulfanyl)phosphoryl]-oxymethane

Methidathion (Supracide),

3-(dimethoxyphosphinothioyl-sulfanyl-methyl)5-methoxy-1,3,4-thiadiazol-2-one
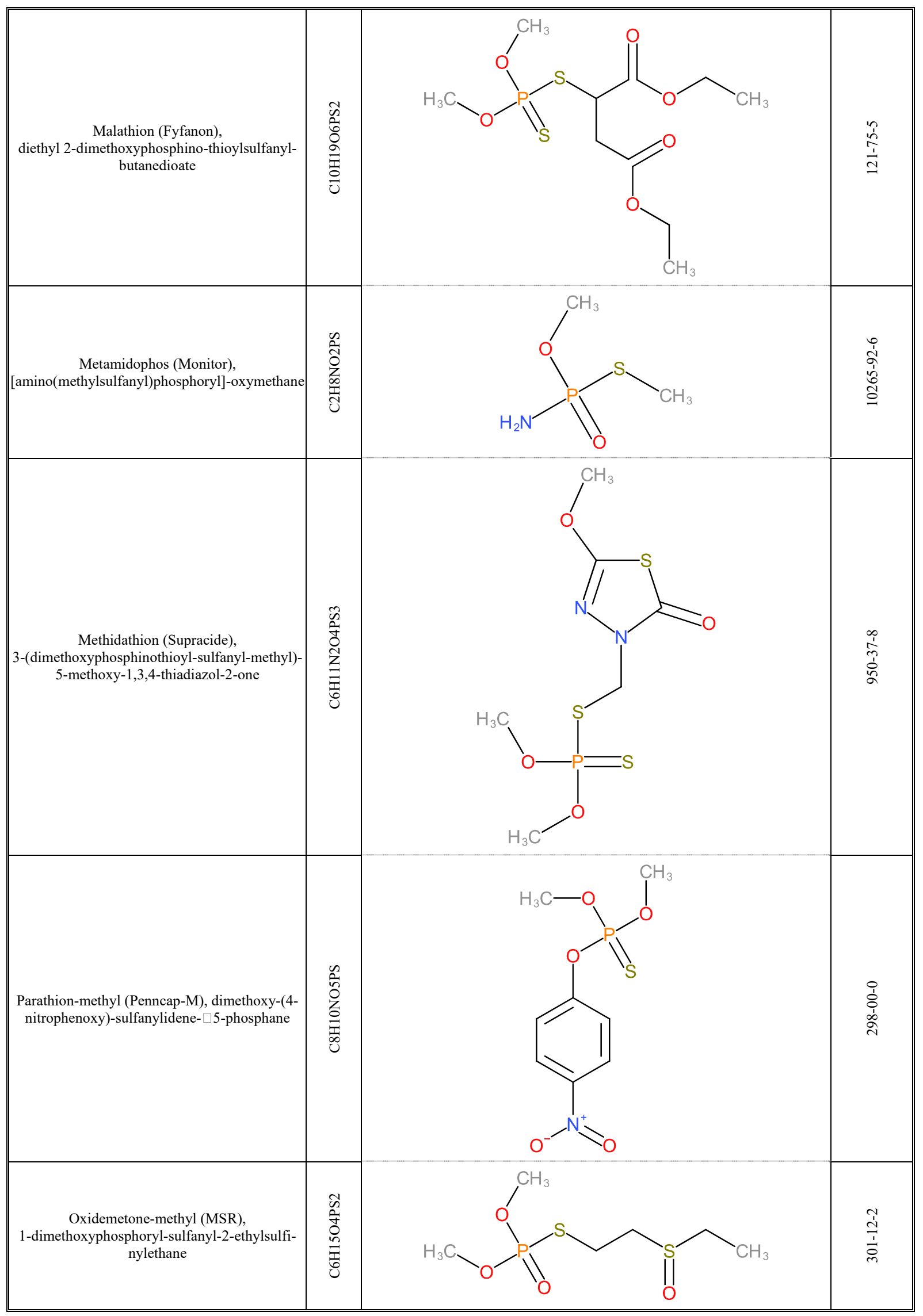


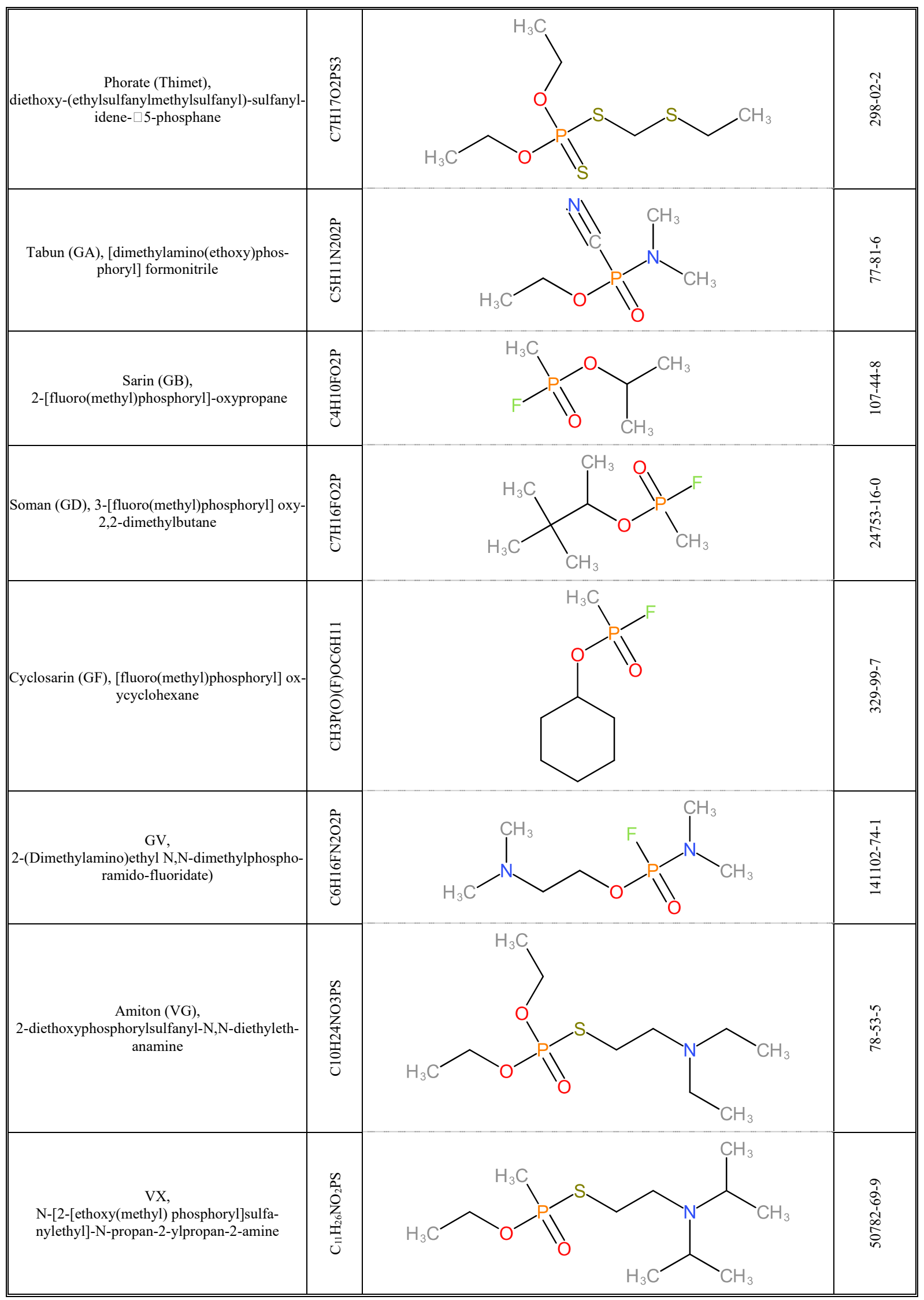




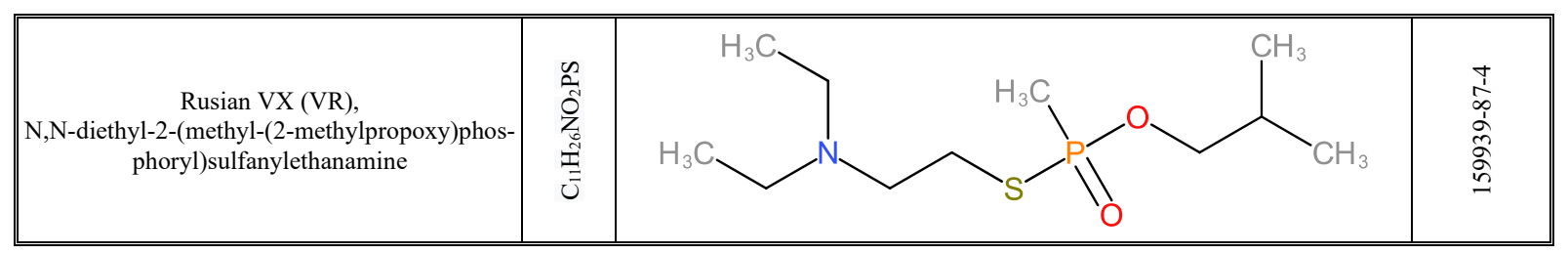

\section{OPs pesticides}

The use of pesticides from the group of OPs is widespread in developed countries in agricultural production and hygiene $[12,19]$. These compounds exhibit different physicochemical properties, such as vapor pressure and solubility in water. They also differ in chemical stability and show different toxicity to warm-blooded animals. Depending on the stability in environmental conditions, some compounds are used in plant protection during sowing, while others can be successfully applied only during the harvest period. The first group must be characterized by persistence in order to avoid secondary action and reduce costs, while the second group of compounds used in the later period should be less stable. In this way, the concentration of residues is regulated, which must be negligible during the harvest period. This group of OPs pesticides includes parathion, as the most powerful representative with the widest spectrum of action (due to high toxicity, it is generally no longer applied), methyl parathion, phosphamidon, phosdrin, dichlorophos, chlorthion, thionazin. An overview of the names and chemical formulas of the most commonly used OP pesticides in the market, as well as the physicochemical properties of some of them are given in Table 3.

Table 3. Physico-chemical properties of some commonly used pesticides in agriculture

\begin{tabular}{|c|c|c|c|c|}
\hline Trivial name & $\begin{array}{l}\text { Vapour pressure } \\
(\mathrm{mmHg})\end{array}$ & $\begin{array}{l}\text { Solubility in } \\
\text { water } \\
\left(\mathrm{mg} \mathrm{dm}^{-3}\right)\end{array}$ & $\begin{array}{c}\mathrm{LC}_{\mathrm{t} 50} \\
\text { inhalation } \\
\left(\mathrm{mg} \mathrm{m}^{-3}\right)\end{array}$ & $\begin{array}{c}L D_{50}{ }^{1} \\
\text { orally } \\
\left(\mathrm{mg} \mathrm{kg}^{-1}\right)\end{array}$ \\
\hline & \multicolumn{2}{|c|}{ at 20 or $25^{\circ} \mathrm{C}$} & \multicolumn{2}{|l|}{ rat } \\
\hline Acephate & $1,7 \times 10^{-6}$ & $8,18 \times 10^{5}$ & & 700 \\
\hline Azinofos-methyl & $1,6 \times 10^{-6}$ & 20,9 & 69 & 7 \\
\hline Chlorpyrifos & $2,03 \times 10^{-5}$ & 1,12 & $>200$ & 82 \\
\hline Diazinon & $9,01 \times 10^{-5}$ & 40 & 3500 & 66 \\
\hline Dimethoate & $8,25 \times 10^{-6}$ & $2,5 \times 10^{4}$ & & 60 \\
\hline Disulfoton & $9,75 \times 10^{-5}$ & 16,3 & 200 & 2,6 \\
\hline Ethoprophos & $3,8 \times 10^{-4}$ & 750 & & 34 \\
\hline Fenamiphos & $1 \times 10^{-6}$ & 329 & 91 & 8 \\
\hline Malathion & $3,38 \times 10^{-6}$ & 143 & 43,79 & 290 \\
\hline Methamidophos & $3,53 \times 10^{-5}$ & $1 \times 10^{6}$ & 162 & 7,5 \\
\hline Methidathion & $3,37 \times 10^{-6}$ & 187 & 50 & 20 \\
\hline Parathion-methyl & $6,68 \times 10^{-6}$ & 11 & 84 & 2 \\
\hline Naled & $2 \times 10^{-4}$ & 1,5 & & 92 \\
\hline $\begin{array}{l}\text { Oxidemetone-me- } \\
\text { thyl }\end{array}$ & $2,85 \times 10^{-5}$ & $1 \times 10^{6}$ & 1500 & 30 \\
\hline Phorate & $6,38 \times 10^{-4}$ & 50 & 11 & 1 \\
\hline
\end{tabular}

${ }^{1}$ LD 50 represents a dose of vapor or aerosol poison needed to cause the death of $50 \%$ of the exposed population, while $\mathrm{ICt}_{50}$ concentration of vapor of the compound in air in the unit of time required to produce a certain physiological effect in $50 \%$ of the population surveyed (based on the normal distribution of the effect supported by legality of the distribution of probability of random events). The most toxic compounds have $\mathrm{LD}_{50}<0.025 \mu \mathrm{g} \mathrm{kg} \mathrm{kg}^{-1}$, highly toxic $\mathrm{LD}_{50}$ from 0.025 to $2.5 \mu \mathrm{g} \mathrm{kg}^{-1}$, and moderately toxic with $\mathrm{LD}_{50}>2.5 \mu \mathrm{g} \mathrm{kg}^{-1}$.

Before it is released into the market, the product must be thoroughly examined and identified how dangerous it is for humans and animals [36]. The development of new plant protection products, safe for mammals and fish, includes synthesis, biological screening, soil evaluation, toxicological testing, metabolic studies, compound degradation testing, environmental safety assessment, patent protection and the production of the product itself [37]. In order to bring the environmental impact of pesticides to an acceptable level, all commercially available products are subject to strict legal regulations in most countries [38].

\section{OPs as CWA}

OPs belonging to CWA group are used in military operations in order to kill, seriously injure or disable exposed persons, expressing their physiological effects [12,22]. Therefore, chemical weapons, together with nuclear (and radiological) as well as biological weapons (NBC or CBR), are classified as weapons of mass destruction (WMD). In principle, chemical weapons involve agents along with systems for their application. Compared to conventional weapons, a relatively small amount of modern warfare from the group of OPs can kill a huge number of people. The CWA from OPs group usually contains one alkyl and one alkoxy group and a fluorine atom as a leaving group. They also have a characteristic $\mathrm{P}-\mathrm{C}$ bond while this bond is not characteristic for insecticides which are therefore less toxic. The most commonly mentioned CWA is sarin, which is also used for terroristic purposes [20,23].

Research at the molecular level confirmed that CWA induces acute stress in the organism, by currently inhibiting AChE and disturbing the concentration of adenocorticotropic hormones in the blood [5]. Taking into account the strength of the toxic effects on the organism and the physiological response of the organism caused by toxic substances, it is possible to make the following distribution of CWA: disabling (irritants - tear gas and kayaks), destroying (suppressants), general blood poisons, throat and nerve poisons, disturbing (psycho chemical poisons).

There are four important series of CWA from OPs group $[5,17]$. Series $G(G$ - German) includes alkyl phosphonofluorides, phosphonofluoridothioates and phosphorus amidocyanides. This is the second generation of chemical agents known as irrefutable. Alkyl and dialkyl S-2dialkylaminoethyl alkylphosphonothiolates, as well as S-2dialkylaminoethyl alkylphosphonoselenoates belong to $\mathrm{V}$ series (V - Venomous, poisonous). The third generation of chemical agents is known as persistent. The GV series, the fourth generation of chemical agents, includes alkyl phosphoramidofluoridates. They are designed to have advantages over less stable G-series compounds and highly toxic V-series agents. The researchers also developed agents that belong to a group of quaternary amine salts with improved ability to penetrate neuromuscular synapses. Novichok series includes carbon monoxide phosphorohalides, which also belong to the fourth generation of chemical agents $[5,19]$. In addition to OP, there are some carbamate $(\mathrm{CM})$ nerve poisons. Table 4 provides an overview of CWA compounds belonging to OPs group, together with their basic toxicological physicochemical parameters and toxicological manifestations in humans. 
Table 4. Physico-chemical properties and toxicological characteristics of chemical warfare agents

\begin{tabular}{|c|c|c|c|c|}
\hline OPs - CWA & GA & GB & GD & $\mathbf{V X}$ \\
\hline $\begin{array}{c}\text { Solubility in water (\%) } \\
\text { at } 25^{\circ} \mathrm{C}\end{array}$ & 10 & Mixed & 2 & $3\left(\infty<9.5^{\circ} \mathrm{C}\right)$ \\
\hline Appearance of liquid & colorless to brownish & transparent, colorless & clear colorless & thick clear to yellowish \\
\hline $\begin{array}{l}\text { Persistence in the envi- } \\
\text { ronment }\end{array}$ & $24-36 \mathrm{~h}$ & $2-24 h$ & relative stable & $2-6 d$ \\
\hline $\begin{array}{l}\text { LCt50 vapor } \\
\left(\mathrm{mg} \mathrm{min} \mathrm{min}^{-1}\right)\end{array}$ & $200-400$ & 100 & 50 & $36-70$ \\
\hline $\begin{array}{l}\text { ICt50 inhalation } \\
\left(\mathrm{mg} \mathrm{min}^{-1} \mathrm{~m}^{-3}\right)\end{array}$ & $100-300$ & $15-75$ & $5-25$ & $5-50$ \\
\hline $\begin{array}{l}\text { LD50 intravenous } \\
\left(\mathrm{mg} \mathrm{kg}^{-1}\right)\end{array}$ & 0,014 & 0,014 & $7-12$ & 0,008 \\
\hline
\end{tabular}

OPs as drugs

Parallel with the discovery of the mechanism of OPs action as AChE prolonged-release inhibitors, the studies on the possible application of isopluorate (DFP) in the treatment of gastrointestinal tract, urinary bladder, myasthenia gravis and glaucoma $[12,20,39]$. However, no advantage of OPs in relation to the previously used short-acting inhibitors $\mathrm{AChE}$ physostigmine and neostigmine were observed. Moreover, the increased risk of cholinergic crises due to overdose, as well as adverse effects on the central nervous system (CNS) due to the increased passage of OP through the blood-brain barrier was observed. Side effects have been partially eliminated during local application of OPs, so DFP and ecothiopate have been used for several years in the treatment of glaucoma. DFP is also used for the treatment and diagnosis of some forms of glaucoma and other eye diseases, such as for example, accommodation isotropy. Also, some strong poisons, such as paraoxon and armin are now used only in special cases, as the long-term administration has been observed to cause permanent changes in the eye lens [40]. Phosphomycin is used as a broad spectrum antibiotic [41] and its effect is based on inhibition of peptidoglycan biosynthesis.

Recent studies have shown that AChE is involved in the development of some types of tumors [42,43]. These findings have opened the way for the potential use of OPs as cytostatics. Cyclophosphamide or endoxan is used in combination with cis-platinum in the treatment of various types of tumors, as well as autoimmune diseases, where it exerts the dose-dependent effect $[44,45]$.

Malathion is also used as an ancillary medical device in patients infected with lice and their eggs in the hair. In addition to azinophos methyl, malathion has a high ovicidal activity [46,47].

\section{Removal of OPs from the environment}

The widespread use of OPs in agriculture contributes to their pronounced presence in food and the environment, which is undesirable due to the toxic effects of these compounds and the products of their transformation $[3,48]$. Extreme use of OPs also leads to the accumulation of their residues in the human body through the food chain, and hence to impairing the function of $\mathrm{AChE}$, cholinergic receptor dysfunction, and even death. For these reasons, there has been a need for rapid and effective monitoring, as well as effective removal of OPs, in order to control their levels in food and the environment [49-52]. Today, there are several strategies to eliminate pesticides, which include their adsorption, degradation and microbiological treatment [3].

\section{Adsorption of $O P$}

Adsorption of organic pollutants on solid adsorbents is one of the most commonly applied and most effective techniques for removing these compounds from water, as well as detoxification of the organism. For this purpose, natural materials as well as materials derived from organic or industrial waste, which can be classified on carbon, inorganic oxide, polymeric and similarly, according to their chemical composition. Adsorption of OPs is usually a pseudo-first or second order process, which follows the model of Langmuir and Freundlich isotherms [53]. Langmuir isotherm suggests monolayer adsorption on a heterogeneous surface with uniformly distributed pores. On the other hand, the diffusion of pesticides in the selected material depends on the physical characteristics and the size of the pores of the solid material. The effectiveness of OPs removal from the environment by various materials depends on the availability of binding sites of adsorbents, as well as on steric disturbances that depend on the structure and functional groups of adsorbates [54]. As an example, one can compare the efficiency of removal of methyl parathion with various solid adsorbents, which, due to steric disturbances and molecular size differences, are higher in seven orders of magnitude compared to ethyl parathion [55]. On the other hand, Freundlich isotherm is used to describe heterogeneous systems and reversible adsorption. It is conducted on the assumption that the surface of adsorbents is heterogeneous with different energy contents in individual points for adsorption.

In the interaction of OPs with carbon materials, the functional groups and the $\pi$ conjugated system on their surface have a dominant role [56-59]. It was found that $\pi-\pi$ interaction on carbon monolithic surfaces leads to the adsorption of pesticides with an aromatic structure, while in the case of pesticides that do not contain an aromatic part adsorption occurs via surface functional groups $[59,60]$. In adsorption processes, the most often used adsorbent for OPs removal is activated carbon due to the developed specific surface and porosity, thermal stability and low acid / basic reactivity $[17,61,62]$. Activated carbon from waste tires achieves a level of adsorption of $88.9 \mathrm{mg} \mathrm{g}^{-1}$ methyl parathion for $60 \mathrm{~min}$ at $\mathrm{pH} 2$ from contaminated water at the initial concentration of $12 \mathrm{mg} \mathrm{l}^{-1}$ [55]. In order to use various carbon materials in the adsorption of OPs, the special attention has been paid to those obtained by carbonization of waste materials from agriculture, industry or biomass $[62,63]$.

A large number of literature data related to the testing of pesticide adsorption on mineral materials, zeolites, polymers and other materials [64-68]. Recently, the special interest in mesoporous materials appeared, since they represent a special class of adsorbents with the large internal surface, adjustable size and pore volume, as well as a stable pore 
network suitable for modification and functionalization $[60,69]$. Mesoporous monetite $\left(\mathrm{CaHPO}_{4}\right)$ is used as an effective adsorbent for removing malathion from aqueous solutions [66]. The results showed that the adsorption capacity (defined as the mass of malathion per unit mass adsorbent) was $52 \mathrm{mg} \mathrm{g}^{-1}$ for the high concentration of malathion, indicating good characteristics taking also into account the low price of this adsorbent. Due to the appropriate characteristics, ordered mesoporous carbons (OMCs) are the promising materials in technologies based on adsorption, in energy and in many other areas of application [60,69-71]. A group of carbon mesoporous materials were used to test adsorption of dimethoate and omethoate in order to remove them from aqueous solutions [69]. It has been shown that the adsorption efficiency increases by introducing low concentrations $(<1 \%)$ of boron, nitrogen or phosphorus into the carbon structure, achieving adsorption capacity up to $164 \mathrm{mg} \mathrm{g}^{-1}$ and adsorption of $80 \%$ $\mathrm{OP}$, as found for a solution of dimethoate at the concentration of $5 \times 10^{-3} \mathrm{~mol} \mathrm{\textrm {dm } ^ { - 3 }}$. Recently, the application of nanostructured composites, a biopolymer based on clay minerals with biocompatible materials, demonstrated high efficiency for the effective removal of dichlorvos from the aquatic environment [72-74]. The adsorption efficiency $93.8 \%$ for $5 \mathrm{~h}$ at $30^{\circ} \mathrm{C}$ was achieved using MMT-CuO-Ch composite at $\mathrm{pH} 10.0$.

In order to remove OPs from the environment, nanoparticles are also used. It has been shown that silver and gold nanoparticles adsorb chlorpyrifos and malathion, and they are effective and cheap water purification materials when applied onto the aluminium substrate [49,75]. Dimethoate and its more toxic analogue omethoate are also adsorbed onto nanoparticles of spherical or rod-shaped gold [70], which is confirmed by the application of various physical-chemical methods (UV-Vis spectrophotometry, TEM, AFM and FTIR). Extremely high adsorption capacity for nanoparticles (456 $\mathrm{mg} \mathrm{g}^{-1}$ ) in relation to the rodent nanoparticles $\left(57.1 \mathrm{mg} \mathrm{g}^{-1}\right)$ showed that the adsorption

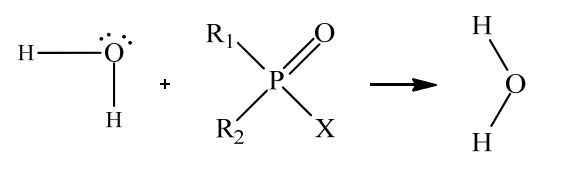

An example, the hydrolysis of sarin, which depends on the acidity of the environment, can be considered. In aqueous solutions, sarin hydrolyzes according to the reaction scheme:

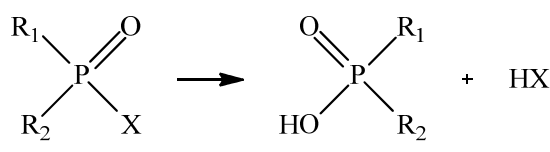

efficiency is highly dependent on the shape and surface coverage of nanomaterial.

The most important ways of OPs chemical degradation are hydrolysis, oxidation and photolysis [76-78]. In all cosystems (soil, water, plants and animals), degradation with the cleavage of $\mathrm{P}=\mathrm{S}$ bond, and then a more toxic oxo-form $(\mathrm{P}=\mathrm{O})$ is formed, replacing sulphur with oxygen in

Hydrolysis of OPs strictly depends on the acidity of the solutions or in the soil. If the halftime of hydrolysis in laboratory conditions $(\mathrm{pH}$ it is below 6 , at a temperature of about $5^{\circ} \mathrm{C}$ ) is 10 days [79], it can increase up to one year in the environment [80]. OPs have been detected in the soil for years after application, which clearly indicates that pesticides can survive for a long time in the environment. It can explained by their adsorption onto particles in the soil inaccessible to microbiological metaphosphorous ester bonds of the thiophosphorous group by nucleophilic or electrophilic attack [81]. In addition to numerous experimental studies of the OPs hydrolysis [76,82-84], the $a b$ initio test for the alkaline hydrolysis of a group of compounds comprising paraoxon, metal parathion, fenitro, demeton-S, acephate, phosalone, azinphos-ethyl and me leaving group (76]. followed by the formation of non-toxic products. The hydrophilic reaction of OPs group CWA is irreversible and begins with the attack of the nucleophilic water molecule on the phosphorus electrophilic element, with the formation of a ransient state, which is then stabilized by separation of HX molecule (eq.1): he thiophosphate bond $(\mathrm{P}=\mathrm{S})$. affects the mechanism of degradation of OPs thio- and oxo-

${ }_{\mathrm{R}_{2}}^{\mathrm{R}_{1}} \mathrm{P}_{\mathrm{X}}^{\mathrm{O}} \rightarrow \mathrm{HO}_{\mathrm{HO}^{\prime}}^{\mathrm{P}_{\mathrm{R}_{2}}^{\prime}}+\mathrm{HX}$

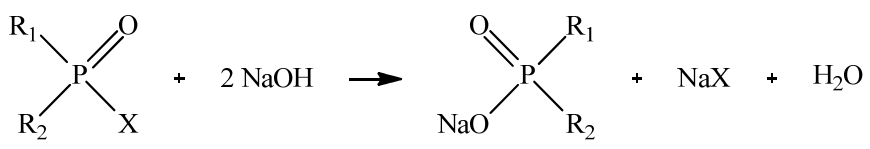

As a result of the formation of hydrofluoric acid and isopropylmethylphosphonic acid, the concentration of hydrogen ions increases with time, so in the acidic environment, the catalytic effect of the $\mathrm{H}^{+}$ions is present. It is known that sarin is rapidly hydrolyzed in low alkaline solution, so sodium carbonate or ammonia solutions can be used for decontamination.

In a diluted sodium hydroxide solution, the hydrolysis of sarin takes place according to the eq.3:

broken (eq.4):

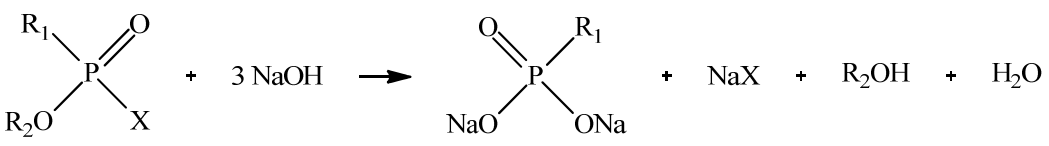


Concentrated alkaline solutions completely dissolve the

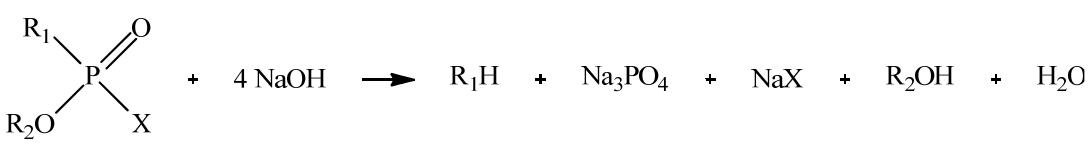

Hydrolysis of sarin is accelerated by the number of agents, such as hypochlorite ions, chromates, molybdates and tungsten $\left(\mathrm{CrO}_{4}{ }^{2-}, \mathrm{MoO}_{4}{ }^{2-}, \mathrm{WO}_{4}{ }^{2-}\right)$, as well as a number of various anions. It is believed that the cause of their catalytic effect is the formation of an anion complex with the sarin molecule, enabling the electrophilic attack of the water molecule on the phosphorus atom. These anions also provide insoluble complexes with phosphate ions. Very active catalysts for sarin hydrolysis are also some cheated metal complexes $\left(\mathrm{Cu}^{2+}, \mathrm{Fe}^{3+}, \mathrm{La}^{3+}\right)$, where cheated ions of divalent copper are particularly distinguished.

Chemical degradation of OP is also due to the use of advanced oxidation processes (AOP), which include photochemical (direct photolysis, photochemical oxidation, photocatalysis) [84-88], and ozone-depletion processes. AOPs are based on the production of $\mathrm{OH}^{*}$, which indiscriminately attacks most organic molecules, leading to partial or total decomposition and transformation to more toxic and/or stable products [89]. Radiolytic degradation leads to degradation of OPs to less toxic and sometimes biodegradable compounds and often results in the formation of $\mathrm{CO}_{2}$ and water [90]. By increasing the gamma irradiation dose to $1.0 \mathrm{kGy}$, the level of diazinon, chlorpyrifos and phosphamidon in tomatoes decreased by $80-95 \%$, depending on the treated pesticide [90]. AOPs that represent a combination of microwave and UV radiation in the presence of $\mathrm{TiO}_{2}$ and $\mathrm{H}_{2} \mathrm{O}_{2}$ allow the removal of up to $100 \%$ OP for 6 min from the beginning of the reaction.

Photodegradation under the influence of sunlight is one of the most destructive methods for degradation of organic compounds [91]. In case of OPs, this process is of limited importance, because most OPs absorb in the UV region [92]. Several publications dedicated to photodegradation of chlorpyrifos have shown that the combination of UV light with catalysts such as $\mathrm{TiO}_{2}$, metal ion and $\mathrm{H}_{2} \mathrm{O}_{2}$ is very effective [83,84]. In addition, direct and indirect degradation leads to the formation of various more or less toxic products or to complete mineralization. For chlorpyrifos it has been found that the rate of catalytic photodegradation depends on the nature of water by the order of distilled water $>$ groundwater $>$ lake $>$ river $>$ drinking water [93].

In our recent paper, technical chlorpyrifos (TCPF) and its oil in water (EW) and emulsifiable concentrate (EC) formulations were irradiated by UV-C, and their photodegradation products were subjected to toxicity assessment, including determination of acetylcholinesterase (AChE) activity, genotoxicity and oxidative stress using human blood cells as a model system [94]. Toxicity studies were performed using the chlorpyrifos concentrations in the range of those proposed as the maximum residue levels in plant commodities. TCPF, EW and EC photodegradation products induced DNA damage and oxidative stress, and their genotoxicity did not decrease as a function of irradiation time. Irradiated TCPF and EC are more potent $\mathrm{AChE}$ inhibitors than irradiated EW. Accordingly, the application of UV-C irradiation must be considered when processing the plants previously treated with chlorpyrifos formulations.

\section{Microbiological treatment of OPS}

One of the promising methods of degradation and detoxification of OPs is enzymatic biodegradation $[10,80,95,96]$. Several OPs degrading enzymes are known, among which the bacterial enzyme phosphoesterase is best characterized. It has the ability to break down different phosphoester bonds [97]. In laboratory conditions $\left(25^{\circ} \mathrm{C}, \mathrm{pH} 7\right)$, biodegradation is about the order of magnitude faster than chemical hydrolysis, which is about ten times faster than photolysis [96].

There are a large number of microorganisms in the environment with enzymes capable of digesting OPs. Enzyme oxidation of thio-forms leads usually to the formation of more toxic oxo-forms, which can be used by bioanalytical methods for the detection of low concentrations of these pollutants. Microbiological degradation has a synergistic effect with chemical degradation in the remediation of contaminated water and soil $[77,98]$.

Some types of bacteria are able to degrade OPs both in water and in the soil. Thus, the biodegradation of chlorpyrifos in the presence of bacterial strain Pseudomonas kilonensis (SRK1) isolated from wastewaters with the addition of chlorpyrifos was studied and optimal conditions for the removal of this OP were determined [99]. On the other hand, the bacterial strain, isolated from the sludge collected at the drainage of the chlorpyrifos production plant, degraded the various O-O-dialkylphosphorothioates and O,O-dialkyl- phosphates [100]. This strain, belonging to the genus Stenotrophomonas, is able to degrade $100 \%$ metalparathion, metallo-paraoxon, diazinon and phoxime, 95\% parathion, $63 \%$ chlorpyrifos, $38 \%$ of profenofos and $34 \%$ of triazophos at a concentration of $50 \mathrm{mg} \mathrm{l}^{-1}$ within 24 hours. A new strain of Bacillus arabhattai strain, labelled SanPS1, has recently been isolated from arable land in India. It is capable to degrade about $56 \%$ chlorpyrifos within 24 hours at the concentration up to $500 \mathrm{mg} \mathrm{ml}^{-1}$ [101].

\section{Removal of OPs from contaminated persons and personal protective agents}

Chemical decontamination aims to neutralize CWA from OPs group within a short time by transforming them into non-toxic products or removing them from the surface, air, water or environment. It is performed by physical, chemical or combined methods. One or more methods of decontamination can be applied as a part of the decontamination procedure, in which way the decontamination can be performed by the application of chemical, physical or mechanical procedures $[23,102,103]$.

The chemical method of decontamination is based on the chemical reactions between decontamination materials and toxic compounds, thereby reducing or eliminating toxicity (harmful effects on biological functions). The physical way of decontamination is based on the processes of physical change of the state of toxic substances (evaporation, etc.), whereby they retain the structure and biological activity. The mechanical method of decontamination is based on changing the position of the contaminants, with the toxic substances 
retaining all their properties. In the chemical methods, the appropriate chemical reactions with the toxic substances must have high reaction rate with large number of CWA, the reaction products should be non-toxic and tolerant for the object that is decontaminated and also for humans (not to irritate the skin, not to be corrosive to metals, and aggressive for clothing). Besides, the reagents (decontamination materials) should be economical for use in large quantities [104,105].

The choice of the appropriate procedure starts from the type of CWA and the objects that are subjected to decontamination, and also the possibilities of applying the appropriate decontamination type and materials. The following procedures for bringing decontamination materials into contact with CWA are usually applied: dusting, spraying with a solution for decontamination, boiling, immersion in solution and steam (paramedic procedure). The quality of the material for the body protection agents are made is checked by modern devices for measuring penetration and permeation of CWA [104].

\section{Acknowledgements}

This work was funded by the Ministry of Education, Science and Technological Development of the Republic of Serbia, within the project OI 172 023, 172045, TR 34034 and the innovation project 391-00-16 / 2017-16 / 3.

\section{References}

[1] FEST,C., SCHMIDT,K.J.: The chemistry of organophosphorus pesticides, Springer Science \& Business Media, Berlin, Germany, 2012. (ISBN 978-3-642-68441-8)

[2] Kwong,T.C.: Ther. Drug Monit., $24 \quad$ (2002) 144. (http://dx.doi.org/10.1097/00007691-200202000-00022)

[3] LAZAREVIĆ-PAŠTI,T., ČOLOVIĆ,M,: Organophosphorus insecticides: Toxic effects and detoxification, In: Organophorous pesticides N. Willkinson, ed, Nova science Publishers, New York, USA, 2016, p.87. (ISBN: 978-1-63485-450-4)

[4] COLEMAN,K.: A history of chemical warfare, Palgrave Mcmillan, Basingstoke, UK 2005. (ISBN 978-1-4039-3460-4)

[5] GUPTA,R.C.: Handbook of toxicology of chemical warfare agents, Academic Press, London, UK, 2015. (ISBN 9780128001592)

[6] Montella,I.R., Schama,R., Valle,D.: Memorias do Instituto Oswaldo Cruz, 107(2012) 437. (http://dx.doi.org/10.1590/S0074$\underline{02762012000400001)}$

[7] MANGAS,I., VILANOVA,E., ESTÉVEZ,J., FRANCA,T., BRAZ,J. Chem. Soc., 27 (2016), 809. (http://dx.doi.org/10.5935/0103$\underline{5053.20160084)}$

[8] KOZAWA,K., AOYAMA,Y., MASHIMO,S., KIMURA,H.: Toxin Rev., 28 (2009), 245. (https://doi.org/10.3109/15569540903297808)

[9] LAZAREVIĆ-PAŠTI,T., NASTASIJEVIĆ,B., VASIĆ,V.: Pestic. $\begin{array}{llll}\text { Biochem. } & \text { Physiol., } & 101 & \text { (2011), }\end{array}$ (https://doi.org/10.1016/i.pestbp.2011.09.009)

[10] LAZAREVIĆ-PAŠTI,T., ČOLOVIĆ,M., SAVIĆ,J., MOMIC,T., VASIC,V.: Pestic. Biochem. Physiol., 100 (2011), 140 (https://doi.org/10.1016/i.pestbp.2011.03.001)

[11] LAZAREVIĆ-PAŠTI,T,. VASIĆ,V.: J. Environ. Prot. Ecol., 12 (2011), $1168 . \quad$ (https://docs.google.com/a/jepejournal.info/viewer? $\mathrm{a}=\mathrm{v} \&$ pid=sites\&srcid=amVwZS1qb3VybmFsLmlu Zm98amVwZS1qb3VybmFsfGd4OjViOTdjNGQ4NDJkNjZIZWI)

[12] ČOLOVIĆ,M., KRSTIĆ,D., LAZAREVIĆ-PAŠTI,T., BONDZIC,A., VASIC,V.: Curr. Neuropharmacol., 11(2013), 315. (http://dx.doi.org/10.2174/1570159X11311030006)

[13] ČOLOVIĆ,M., VASIĆ,V., AVRAMOVIĆ,N., GAJIĆ,M., DJURIĆ,D., KRSTIĆ,D.: Toxicol. Lett, 233 (2015), 29. (https://doi.org/10.1016/j.toxlet.2015.01.003)

[14] ČOLOVIĆ,M., LAZAREVIĆ-PAŠTI,T., VASIĆ,V.: Toxic effects of chlorpyrifos and its metabolites on some physiologically important enzymes: Atp-ases, cholinesterases, peroxidases, In: Chlorpyrifos, N.Wilkinson, ed. Nova publishers, New York,USA, 2015, p.87.
(ISBN 978-1-63482-112-4)

[15] LAZAREVIĆ-PAŠTI,T., BONDŽIĆ,A., PAŠTI,I., VASIC,V.: $\begin{array}{llll}\text { Pestic. Biochem. } & \end{array}$ (https://doi.org/10.1016/j.pestbp.2012.09.004)

[16] LAZAREVIĆ-PAŠTI,T., BONDŽIĆ,A., PAŠTI,I., MENTUS,S., VASIC,V.: J. Electroanal. Chem., 692 (2013), 40. (https://doi.org/10.1016/j.jelechem.2013.01.005)

[17] GUPTA,V.K., GUPTA,B., RASTOGI,A., AGARWAL,S. NAYAK,A.: $\quad$ Water Res., $45 \quad$ (2011), 4047 (https://doi.org/10.1016/j.watres.2011.05.016)

[18] KAMEL,A., BYRNE,C., VIGO,C., FERRARIO,J., STAFFORD,C., VERDIN,G., SIEGELMAN,F., KNIZNER,S., HETRICK,J.: Water Res., 43 (2009), 522. (https://doi.org/10.1016/j.watres.2008.10.038)

[19] MARRS,T., MAYNARD,R., SIDELL,F.: Chemical warfare agents: toxicology and treatment, John Wiley \& Sons, New York, USA, 2007. (ISBN: 978-0-470-01359-5)

[20] VUČEMILOVIĆ,A.: Arch. Industr. Hyg. Tox., 61 (2010), 247. (https://doi.org/10.2478/10004-1254-61-2010-1995)

[21] LAZAREVIĆ-PAŠTI,T., LESKOVAC,A., $\quad$ MOMIĆ,T., PETROVIC,S., VASIC,V.: Curr. Med. Chem., 24(2017), 3283. (https://doi.org/10.2174/09298667324666170705123509)

[22] BOUBLIK,Y., SAINT-AGUET,P., LOUGARRE,A., ARNAUD,M., VILLATTE,F., ESTRADA-MONDACA,S., FOURNIER,D.: Protein Eng., 15 (2002), 43. (https://doi.org/10.1093/protein/15.1.43)

[23] TU,A.T.: Toxin rev., $26 \quad$ (2007), 231 (https://doi.org/10.1080/15569540701496321)

[24] LAZAREVIĆ-PAŠTI,T., LESKOVAC,A., VASIĆ,V.: Curr. Drug $\begin{array}{llll}\text { Metab., } & 16 & \text { (2015), } & 168\end{array}$ (https://doi.org/10.2174/138920021603150812120640)

[25] JOHNSON,M.K., JACOBSEN,D., MEREDITH,T.J. et al.: Emergency med., 12 (2000), 22. (https://doi.org/10.1046/j.14422026.2000.00087.x)

[26] JOKANOVIĆ,M.: Toxicol. Lett., $190 \quad$ (2009), 107. (https://doi.org/10.1016/j.toxlet.2009.07.025)

[27] KUCA,K., GUPTA,R.C., MUSILEK,K. et al.: Toxin rev., 28 (2009), 238. (https://doi.org/10.3109/15569540903246144)

[28] DUMAS,D., DURST,H.D., LANDIS,W.G., RAUSHEL,F.M. WILD,J.R.: Arch. Biochem. Biophys., 277 (1990), 155. (https://doi.org/10.1016/0003-9861(90)90564-F)

[29] BOKONJIĆ,D., ROSIĆ,N.: Arhiv za higijenu rada i toksikologiju, 42 (1992), 359. (https://hrcak.srce.hr/148838)

[30] SIKDER,A. K., DUBE,S.N., JAISWAL,D.K.: Structure-activity of pyridinium oximes as antidotes to organophosphorus anticholinesterase agents, in: Enzymes of the cholinesterase family, Daniel M. Quinn, et al. (eds.) Springer, Boston, MA, USA, 1995, p.412. (ISBN 978-1-4899-1051-6)

[31] STOJILJKOVIĆ,M.P., JOKANOVIĆ,M.: Arhiv za higijenu rada $i$ toksikologiju, 57 (2006), 435. (https://hrcak.srce.hr/6002)

[32] MURRAY,D.B., EDDLESTON,M., THOMAS,S. et al., Ann. $\begin{array}{lllll}\text { Emergency } & \text { Med., } & 60 & \text { (2012), } & 424 .\end{array}$ (https://doi.org/10.1016/j.annemergmed.2012.05.013)

[33] PETER,J.V., MORAN,J.L., GRAHAM,P.: Criticalcare Med., 34 (2006), 502 (https://doi.org/10.1097/01.CCM.0000198325.46538.AD)

[34] ČOLOVIĆ,M., KRSTIĆ,D., VASIĆ,V. et al.: Chem. Ind., 67 (2013), str 217. (https://doi.org/10.2298/HEMIND120323060C)

[35] TANG,W., RUAN,F., CHEN,Q. et al.: Resp. Care, 61 (2016), 965. (http://rc.rcjournal.com/content/61/7/965)

[36] BOOBIS,A.R., OSSENDORP,B.C., BANASIAK,U. et al.: Toxicol. Lett., 180 (2008), 137. (https://doi.org/10.1016/j.toxlet.2008.06.004)

[37] MUNOZ-QUEZADA,M.T., LUCERO,B.A., IGLESIAS,V.P. et al.: Int. J. Occup. Environ. Health, 22 (2016), 68. (https://doi.org/10.1080/10773525.2015.1123848)

[38] BALLANTYNE,T., MARRS,T.C.: Clinical and Experimental Toxicology of Organophosphates and Carbamates, ButterworthHeinemann, Oxford, Boston, USA, 1992. (ISBN 9781483193656)

[39] GRANT,W.M.: Toxicology of the Eye, 3rd ed. Charles C. Thomas Publisher, Springfield, IL, USA 1986. (https://doi.org/10.3109/15569528709052171)

[40] RAZ,R.: Clin. Microbiol. Infect., 18 (2012), 4 (https://doi.org/10.1080/10.1111/j.1469-0691.2011.03636.x) 
[41] CHENG,K., SAMIMI,R., XIE,G. et al.: Amer. J. Phys. gastrointestinal and liver physiology, 295 (2008), G591. (https://doi.org/10.1152/ajpgi.00055.2008)

[42] XI,H., WU,R., LIU,J. et al.: Thoracic Canc., 6 (2015), 390 (https://doi.org/10.1111/1759-7714.12249)

[43] KASHYAPE,P., TAYLOR,E., NG,J. et al.: Europ. J. Paed. Neurol., 16 (2012), 74. (https://doi.org/10.1016/j.ejpn.2011.07.005)

[44] MCGUIRE,W., HOSKINS,W. BRADY,M. et al.: N. Engl. J. Med., 334 (1996), (https://doi.org/10.1016/10.1056/NEJM199601043340101)

[45] HOFFMANN,E.J., MIDDLETON,S.M., WISE,J.C.: J. Insect Sci., 8 (2008), 1. (https://doi.org/10.1673/031.008.2901)

[46] VERMA,P., NAMDEO,C.: Indian journal of dermatology, 60 (2015), 238. (https://doi.org/10.4103/0019-5154.156339)

[47] GREAVES,A.K., LETCHER,R.J.: Bulletin of environmental contamination and toxicology, $98 \quad$ (2017), 2. (https://doi.org/10.1002/etc.2107)

[48] BOOTHARAJU,M.S., PRADEEP,T.: Langmuir, 28 (2012), 2671. (https://doi.org/10.1021/la2050515)

[49] HE,J., SONG,L., CHEN,S. et al.: Food Chem., 187 (2015), 331. (https://doi.org/10.1016/j.foodchem.2015.04.069)

[50] RASMUSSEN,J.J., IBERG-LARSEN,W.P., BAATTRUPPEDERSEN,A. et al.: Water Res., 84 (2015), 25. (https://doi.org/10.1016/j.watres.2015.07.021)

[51] WANG,X. XING,H., JIANG,Y. et al.: Food Chem. Toxicol., 62 (2013), 148. (https://doi.org/10.1016/j.fct.2013.08.044)

[52] HAMEED,B.H., SALMAN,J.M., AHMAD,A.L.: Hazard. Mater. J. 163 (2009), 121. (https://doi.org/10.1016/j.jhazmat.2008.06.069)

[53] LAZAREVIĆ-PAŠTI,T., ANIĆIJEVIĆ,V., BALJOZOVIĆ,M., ANIĆIJEVIĆ,D.V., GUTIĆ,S., VASIĆ,V., PAŠTI,I.A.: (2018). The impact of the structure of graphene-based materials on the removal of organophosphorus pesticides from water, Environmental Science: Nano, 5(6), 1482-1494. (http://dx.doi.org/10.1039/C8EN00171E)

[54] LAZAREVIĆ-PAŠTI,T., MOMIĆ,T., RADOJEVIĆ,M., VASIC,V.: Pestic. Biochem. Physiol., $107 \quad$ (2013), 55. (https://doi.org/10.1016/j.pestbp.2013.05.004)

[55] TABASSUM,N., RAFIQUE,U., BALKHAIR,K.S. et al.: Biomed Res. Int., 2014(2014), 8. (http://dx.doi.org/10.1155/2014/831989)

[56] AYRANCI,E., HODA,N.: Chemosphere, 57 (2004), 755. (https://doi.org/10.1016/j.chemosphere.2004.08.042)

[57] MALIYEKKAL,S., SREEPRASAD,T.S., KRISHNAN,D. et al.: Small 9 (2013), 273 (https://doi.org/10.1016/10.1002/smll.201201125)

[58] VASIĆ ANIĆIJEVIĆ,D., PEROVIĆ,I., MASLOVARA,S. et al.: Maced. J. Chem. Chem. Eng., 35 (2016), 1. (http://dx.doi.org/10.20450/mjece.2016.1038)

[59] VUKČEVIĆ,M., KALIJADIS,A., BABIĆ,B. et al.: J. Serb. Chem. Soc., 78 (2013), 1617. (https://doi.org/10.2298/JSC131227006V)

[60] WU,Z., ZHAO,D.: Chem. Commun., 47 (2011), 3332. (https://doi.org/10.1039/C0CC04909C)

[61] FOO,K.Y., HAMEED,B.H.: J. Hazard. Mater., 175 (2010), 1. (https://doi.org/10.1016/j.jhazmat.2009.10.014)

[62] SALEH,T., GUPTA,V.: Adv. Colloid Interface Sci., 211(2014), 93. (https://doi.org/10.1016/j.cis.2014.06.006)

[63] IOANNIDOU,O.A., ZABANIOTOU,A.A., STAVROPOULOS,G.G. $\begin{array}{lllll}\text { et } \quad \text { al.: } \quad \text { Chemosphere, } \quad 80 & \text { (2010), } & 1328 .\end{array}$ (https://doi.org/10.1016/j.chemosphere.2010.06.044)

[64] BRUNA,F., PAVLOVIĆ,I., BARRIGA,C. et al.: Appl. Clay Sci., 33 (2006), 116. (https://doi.org/10.1016/j.clay.2006.04.004)

[65] LEOVAC,A., VASYUKOVA,E., IVANČEV-TUMBAS,I. et al.: RSC Adv., 5 (2015), 8122. (https:// doi.org/10.1039/C4RA03886J)

[66] MIRKOVIĆ,M.M., LAZAREVIĆ PAŠTI,T., DOŠEN,A. et al.: RSC Adv., 6 (2016), 12219. (https:// doi.org/10.1039/C5RA27554G)

[67] VALIČKOVÁ,M., DERCO,J., ŠIMOVIČOVÁ,K.: Acta chimica slovaca, 6 (2013), 25. (https://doi.org/10.2478/acs-2013-0005)

[68] WANG,P., YIN,Y., GUO,Y. et al.: RSC Adv., 6 (2016), 10615. (https://doi.org/10.1039/C5RA24248G)

[69] LAZAREVIĆ-PAŠTI,T., PAŠTI,I., JOKIĆ,B. et al.: RSC Adv., 6 (2016), 62128. (https://doi.org/10.1039/c6ra06736k)
[70] MOMIĆ,T., LAZAREVIĆ PAŠTI,T., BOGDANOVIĆ,U. et al.: J. Nanomater., 2016 (2016). (http://dx.doi.org/10.1155/2016/8910271)

[71] PAŠTI,I., GAVRILOV,N., DOBROTA,A.S. et al.: Electrocatalysis, 6 (2015), 498. (http:// dx.doi.org/10.1007/s12678-015-0271-0)

[72] CELIS,R., ADELINO,M.A., HERMOSÍN,M.C. et al.: J. Hazard. Mater., 209(2012),
(https://doi.org/10.1016/j jhazmat 2011.12.074)

73] PEREIRA,F., SOUSA,K.S., CAVALCANTI,G. et al.: Int. J. Biol. Macromol., $\quad 61(2013), \quad 471$ (https://doi.org/10.1016/j.ijbiomac.2013.08.017)

[74] SAHITHYA,K., DAS,D., DAS,N.: J. Mol. Liq., 211(2015), 821. (https://doi.org/10.1016/j.molliq.2015.08.013)

[75] PRADEEP,T.: Thin solid films, 517 (2009), 6441. (https://doi.org/10.1016/j.tsf.2009.03.195)

[76] DYGUDA-KAZIMIEROWICZ,E., ROSZAK,S., SOKALSKI,A.: J. $\begin{array}{lllll}\text { Phys. } & \text { Chem. } & \text { B, } & 118 & \text { (2014), }\end{array}$ (https://doi.org/10.1021/jp503382j)

[77] MURILLO,R., SARASA,J., LANAO,M. et al.: Water Sci. Technol. Water supply, 10 (2010), 1. (https://doi.org/10.2166/ws.2010.777)

[78] WU,T., JANS,U.: Environ. Sci. Technol., 40 (2006), 784. (https://doi.org/10.1021/es051468a)

[79] ELLISON,D.H.: Handbook of chemical and biological warfare agents. CRC press, New York, USA, 2007 (ISBN 9780849314346)

[80] RAGNARSDOTTIR,K.V.: J. Geol. Soc., 157 (2000), 859. (https://doi.org/10.1144/jgs.157.4.859)

[81] LAI,K., STOLOWICH,N.J., WILD,J.R.: Arch. Biochem. Biophys., 318 (1995), 59. (https://doi.org/10.1006/abbi.1995.1204)

[82] HAY,R.W., GOVAN,N., PARCHMENT,K.E.: Inorg. Chem. Commun., 1 (1998), 228. (https://doi.org/10.1016/S13877003(09)00062-8)

[83] HOSSAIN,M.S., FAKHRUDDIN,A.N.M., CHOWDHURY,M. et al.: J. Environ. Chem. Eng., 1(2013), 270. (https://doi.org/10.1016/j.jece.2013.05.006)

[84] BURROWS,H.D., SANTABALLA,J.A., STEENKEN,S.: J.

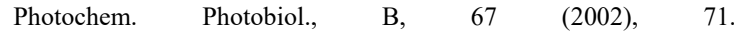
(https://doi.org/10.1016/S1011-1344(02)00277-4)

[85] DERBALAH,A., NAKATANI,N., SAKUGAWA,H.: Chemosphere, 57 (2004), 635. (https://doi.org/10.1016/j.chemosphere.2004.08.025)

[86] HIRAHARA,Y., UENO,H., NAKAMURO,K.: Water Res., 37 (2003), 468. (https://doi.org/10.1016/S0043-1354(02)00272-5)

[87] KONSTANTINOU,I.K., ALBANIS,T.A.: Appl. Catal., B, 42 (2003), 319. (https://doi.org/10.1016/S0926-3373(02)00266-7)

[88] WU,J., LAN,CHAN,C., GILBERT,Y.: Chemosphere, 76 (2009), 1308. (https://doi.org/10.1016/j.chemosphere.2009.04.060)

[89] BAVCON KRALJ,M., ČERNIGOJ,U., FRANKO,M. et al.: Water Res., 41 (2007), 4504. (https://doi.org/10.1016/j.watres.2007.06.016)

[90] ISMAIL,M., KHAN,H.M., SAYED,M. et al.: Chemosphere, 93 (2013), 645. (https://doi.org/10.1016/j.chemosphere.2013.06.051)

[91] KATAGI,T.: Rev. Environ. Contamin. Toxicol., 182 (2004), 1. (h ttps://doi.org/10.1007/978-1-4419-9098-3 1)

[92] AMARATHUNGA,A.A.D., KAZAMA,F.: J. Hazard. Mater., 280 (2014), 671. (https://doi.org/10.1016/j.jhazmat.2014.08.063)

[93] MUHAMAD,S.: Arabian J. Chem., 3 (2010) 127. (https://doi.org/10.1016/j.arabjc.2010.02.009)

[94] SAVIC,J., PETROVIC,S., LESKOVAC,A., LAZAREVICPASTI,T., NASTASIJEVIC,B., TANOVIC,B., GASIC,S., $\begin{array}{lllll}\text { VASIC,V.: } & \text { Food } \quad \text { Chem., } & 271 & \text { (2019), } 469 .\end{array}$ (https://doi.org/10.1016/j.foodchem.2018.07.207)

[95] RAUSHEL,F.M.: Curr. Opin. Microbiol., 5 (2002), 288. (https://doi.org/10.1016/S1369-5274(02)00314-4)

[96] SINGH,B.K., WALKER,A.: FEMS Microbiol. Rev., 30 (2006), 428. (https://doi.org/10.1111/j.1574-6976.2006.00018.x)

[97] GHANEM,E., RAUSHEL,F.M.: Toxicol. Appl. Pharmacol., 207 (2005), 459. (https://doi.org/10.1016/j.taap.2005.02.025)

[98] SAMET,Y., AGENGUI,L., ABDELHÉDI,R.: Chem. Eng. J., 161 (2010), 167. (https://doi.org/10.1016/j.taap.2005.02.025)

[99] KHALID,S., HASHMI,I., KHAN,S.J.: J. Environ. Manage., 168 (2016), 1. (https://doi.org/10.1016/j.jenvman.2015.11.030)

[100] DENG,S., CHEN,Y., WANG,D. et al.: J. Hazard. Mater., 297 (2015), 17. (https://doi.org/10.1016/j.jhazmat.2015.04.052) 
[101] PAILAN,S., GUPTA,D., APTE,S. et al.: International biodeterioration \&biodegradation, 103 (2015), 191. (https://doi.org/10.1016/j.ibiod.2015.05.006)

[102] KARKALIĆ,R., MASLAK,V., NIKOLIĆ,A. et al.: Zaštita materijala, 56 (2015), 239.

(https://doi.org/10.5937/ZasMat1502239K)

[103] KARKALIĆ,R.M., IVANKOVIĆ,N.D., JOVANOVIĆ,D.B. et al.: Indian journal of fibre \& textile research, 41 (2016), 402. (http://nopr.niscair.res.in/handle/123456789/39047)
[104] OTRISAL,P., $\quad$ FLORUS,S.: $\quad$ Hygiena, 58 (2013), 125. (https://doi.org/10.21101/hygiena)

[105] OTRISAL,P., FLORUS,S.: Chemicke listy 108 (2014), 1168 (http://www.chemicke-listy.cz/ojs3/index.php/chemicke$\underline{\text { listy/article/view/429/429) }}$

\title{
Estri organofosfornih kiselina, toksičnost, primena i uklanjanje iz životne sredine
}

\begin{abstract}
Estri organofosfornih kiselina su danas u upotrebi širom sveta. Primenjuju se kao pesticidi, lekovi i bojni otrovi. Njihova akutna toksičnost pripisuje se inhibiciji acetilholinesteraze, koja je ključni enzim u prenošenju nervnih impulsa kod sisara. Toksični efekat estara organofosfornih kiselina manifestuje se akumulacijom acetilholina, što može dovesti do niza neželjenih efekata, uključujući paralizu ili čak smrt. Terapija trovanja organofosfatima zasniva se na primeni specifičnih protivotrova, kao i različitih nespecifičnih i simptomatskih tretmana. U ovom preglednom članku daćemo prikaz najnovijih dostignuća na polju zaštite od negativnog dejstva organofosfata, kao i pregled novih metoda za njihovo uklanjanje iz životne sredine i dekontaminaciju osoba koje su došle u neposredan kontakt sa estrima organofosfornih kiselina.
\end{abstract}

Ključne reči: estri organofosfornih kiselina, pesticidi, nervni agensi, toksičnost, životna sredina, remedijacija. 